\title{
Concentrations of heavy metals in macroalgae in the tropical western Atlantic
}

\author{
S. J. Macedo ${ }^{1}$, S. C. S. Calado ${ }^{2}$, M. L. Koening ${ }^{1}$, V. L. Silva ${ }^{2}$ \\ \& S. Neumann-Leitão ${ }^{1}$ \\ ${ }^{I}$ Department of Oceanography, Federal University of Pernambuco, \\ Brazil \\ ${ }^{2}$ Department of Chemistry, Federal University of Pernambuco, Brazil
}

\begin{abstract}
Studies of heavy metal (copper, lead, zinc and iron) in two species of red macroalgae Gracilariopsis carolinensis Liao and Hommersand and Hypnea musciformis (Wulfen) Lamouroux were carried out to monitor the level of bioavailable metals in coastal areas. The macroalgae and hydrological data were sampled in two areas, at the north and south littoral of Pernambuco (Brazil). The metal concentrations were measured by Atomic Emission Spectrophotometer with Inductive Coupled Plasma. Water temperature ranged from 28 to $31^{\circ} \mathrm{C}$, salinity from 26.4 to 36.9 UPS and dissolved oxygen from 2.43 to $6.37 \mathrm{~mL} . \mathrm{L}^{-1}$. Higher metal concentrations were detected in the south coast, where Hypnea musciformis presented greater retention capacity. A Principal Components Analysis was performed and explained $50.45 \%$ of the total data variability. Rainfall presented an important role in the algae metal content. The median metal concentrations of $G$. carolinensis in the North area were: iron $141 \mu \mathrm{g} . \mathrm{g}^{-1}$, lead $3.50 \mu \mathrm{g} . \mathrm{g}^{-1}$, copper $0.95 \mu \mathrm{g} . \mathrm{g}^{-1}$ and zinc $33.14 \mu \mathrm{g} . \mathrm{g}^{-1}$; in the South area: iron $347 \mu \mathrm{g} . \mathrm{g}^{-1}$, lead $2.99 \mu \mathrm{g} . \mathrm{g}^{-1}$, copper $1.57 \mu \mathrm{g} . \mathrm{g}^{-1}$ and zinc $28.57 \mu \mathrm{g} . \mathrm{g}^{-1}$; and to $H$. musciformis in the North area: iron $675 \mu \mathrm{g} . \mathrm{g}^{-1}$, lead $8.90 \mu \mathrm{g} \cdot \mathrm{g}^{-1}$, copper 1.85 $\mu \mathrm{g} . \mathrm{g}^{-1}$ and zinc $49.93 \mu \mathrm{g} \cdot \mathrm{g}^{-1}$; in the South area: iron $806 \mu \mathrm{g} \cdot \mathrm{g}^{-1}$, lead $5.49 \mu \mathrm{g} \cdot \mathrm{g}^{-1}$, copper $2.35 \mu \mathrm{g} . \mathrm{g}^{-1}$ and zinc $44.57 \mu \mathrm{g} . \mathrm{g}^{-1}$. No significant $(\mathrm{p}<0.05)$ seasonal changes in metal concentration and no distribution pattern were observed in the studied area.
\end{abstract}

Keywords: heavy metal, macroalgae, tropical region. 


\section{Introduction}

One of the undesirable consequences of increasing industrial activity is the increase in metal concentrations in natural water sources, caused by the large output of industrial effluents contaminated with heavy metals [1]. Heavy metal concentrations in macroalgae are used to monitor the level of bioavailable metals in estuarine and coastal areas. Macroalgae provide a time-integrated picture of the bioavailable pollutants [2] and have a relatively longlife span, offering an environmental picture over extensive periods of time [3]. Algae accumulate metals by means of a two-stage process, consisting first of a rapid, reversible physico-chemical process of adsorption on the exterior surface, and then of a slower metabolically regulated intracellular uptake [4]. Consequently, metal concentrations are greatly dependent both on external factors which affect metal interactions with the cell wall $(\mathrm{pH}$, salinity, inorganic and organic complexing molecules) and on physico-chemical parameters which control the metabolic rate (temperature, light, oxygen and nutrients). Since metal binding on the external wall is a continuous process during the life-span of algae, older tissues usually contain higher amounts of many metals [5].

Algae bind only free metal ions, the concentrations of which depend on the nature of suspended particulate matter, and on the seasons of the year regardless of the environmental concentrations $[6,7]$.

There are many macroalgae species in Brazil with economic potential, and some of them have been exploited for decades for mucilage production [8, 9], however few papers discuss heavy metals concentrations and their effects on the biota.

The heavy metals here studied come from different industrial and urban sources in land (electroplating, textile dying, photographic printing, insecticides, tanning, pigments, gasoline combustion, beverages, galvanic plants, paper, dyes, battery, metallic product plants, burning of fuels, etc.) $[10,11]$.

This study had the aim of evaluating the concentration of heavy metals (copper, iron, lead and zinc) in two macroalgae species (Hypnea musciformis and Gracilariopsis carolinensis), to monitor the level of bioavailable metals in tropical coastal areas.

\section{Materials and methods}

\subsection{Study area}

The areas selected for this study are located in the north (Itamaracá Island) and south (Piedade beach) coast of Pernambuco State (Brazil), where occur algae banks influenced by urban and industrial pollution (Fig. 1).

Itamaracá station is located at $7^{\circ} 34^{\prime} 00^{\prime}$ 'S and $34^{\circ} 48^{\prime} 48^{\prime \prime} \mathrm{W}$ and Piedade station at $08^{\circ} 09^{\prime} 17^{\prime \prime} \mathrm{S}$ and $34^{\circ} 55^{\prime} \mathrm{W}$. The clime is tropical, Am' type with transition to the As' (Koeppen classification) with an average air temperature of $27^{\circ} \mathrm{C}$ [12]. In the north station the pollution are derived from the rivers Botafogo, Igarassu and Jaguaribe, and in the south from Pirapama and Jaboatão, all of these rivers receiving a high load of domestic and industrial sewages. 


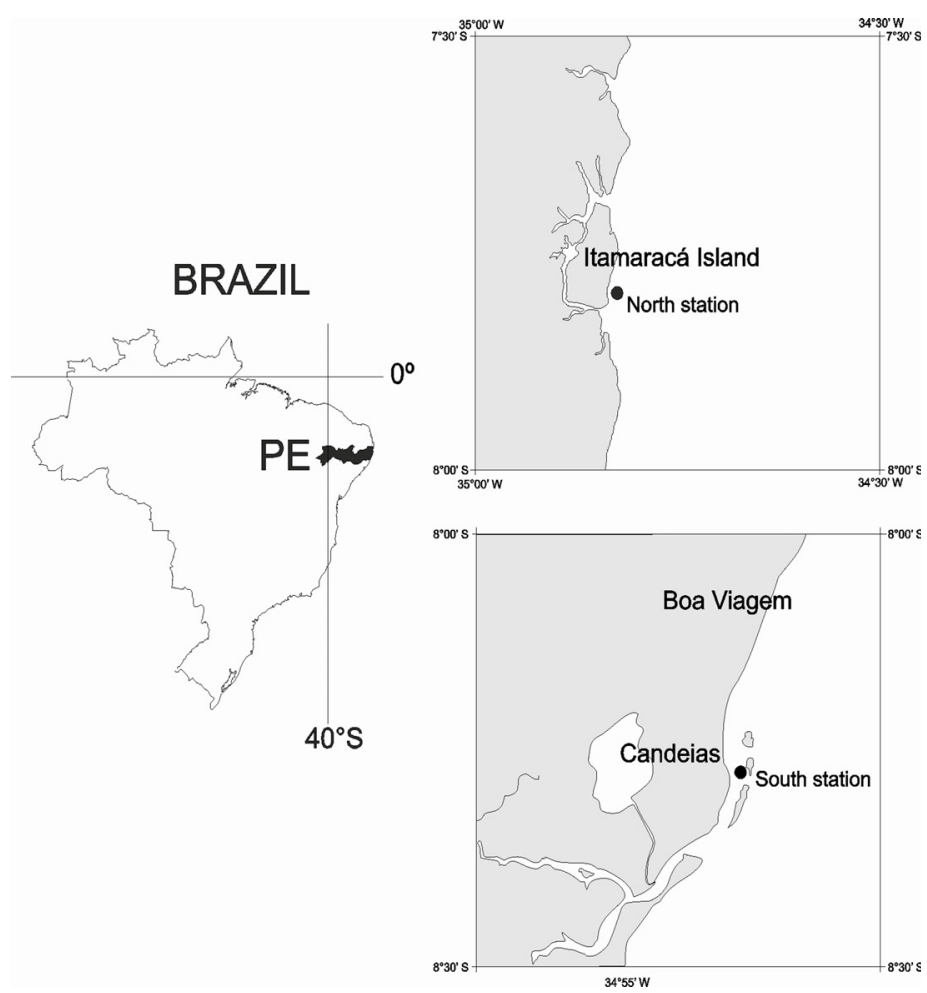

Figure 1: $\quad$ Studied area and stations in Pernambuco State (Brazil).

\subsection{Methodology}

To measure the heavy metals (copper, lead, iron and zinc), Hypnea musciformis and Gracilariopsis carolinensis species were selected due their abundance and high adherence to the reefs. The samples were monthly collected from May 2000 to April 2001, randomly collected through free diving, during spring low tides. In laboratory, the macroalgae were cleaned to remove the epiphytes, and washed with purified water. After they were dried in an oven $\left(50 \pm 5^{\circ} \mathrm{C}\right)$ until obtain a constant weight, than grinded in glass mortar, sieved, and homogenized to obtain a gram size of $500 \mu \mathrm{m}$.

A quantity of $0.5 \mathrm{~g}$ of the sample was treated with $10 \mathrm{~mL}$ of $\mathrm{HNO}_{3}$ at $65 \%$ and $5 \mathrm{~mL}$ of concentrated $\mathrm{HClO}_{4}$. Each sample was digested at $150^{\circ} \mathrm{C}$ for \pm 4 hours. After digestion, each sample was cooled, diluted to $25 \mathrm{~mL}$ with $\mathrm{HNO}_{3}$ $0.1 \mathrm{~N}$ and filtered in Whatman paper 541 (black strip). The metal content was measured by Atomic Absorption Spectrometer (Perkin Elmer AA100 model).

The methodology was validated by the certified material from the International Community Bureau of Reference (BCR/CRM 279-Ulva lactuca). The validation was conducted according to Kane [13], based on International for Standardization Organization - 1989. 
The Principal Components Analysis (PCA) was computed based in a data matrix formed by heavy metals in macroalgae, rainy and hydrological data. Data analyses were carried out using the Numerical Taxonomy and Multivariate Analyses System - NTSYS - ver. 2.1 (Metagraphics Software Corporation, California - USA, 2000).

\section{Results}

\subsection{Heavy metals in Gracilariopsis carolinensis (Fig. 2)}

Iron - In the North area, the highest value of iron was recorded in July $(304 \mu \mathrm{g}$ $\left.\mathrm{g}^{-1}\right)$ and the lowest in March $\left(86 \mu \mathrm{g} \mathrm{g}^{-1}\right)$. In the South area, the highest values were observed in October $\left(666 \mu \mathrm{g} \mathrm{g}^{-1}\right)$, followed by September $\left(621 \mu \mathrm{g} \mathrm{g}^{-1}\right)$, and the lowest value was recorded in January $\left(227 \mu \mathrm{g} \mathrm{g}^{-1}\right)$. The values of the South area were much higher than those of the North area for this species.

Copper - In the North area, the highest copper value was in July $\left(5.74 \mu \mathrm{g} \mathrm{g}^{-1}\right)$ and the lowest was under the detection limit $\left(0.674 \mu_{\mathrm{g} \mathrm{g}^{-1}}\right)$ and were registered in May, September, December, January and March. In the South area, the highest copper amount was in April $2001\left(3.43 \mu \mathrm{g} \mathrm{g}^{-1}\right)$, followed by May $2000(3.30 \mu \mathrm{g}$ $\left.\mathrm{g}^{-1}\right)$, while the lowest was in October $\left(0.80 \mu \mathrm{g} \mathrm{g}^{-1}\right)$. In the North area, these values showed an irregular distribution pattern.

Zinc - In the North area, the highest content of zinc was recorded in July (59.75 $\left.\mu \mathrm{g} \mathrm{g}^{-1}\right)$ and the lowest in September $\left(15.41 \mu \mathrm{g} \mathrm{g}^{-1}\right)$. In the South area, the highest value was observed in April $2001\left(57.49 \mu \mathrm{g} \mathrm{g}^{-1}\right)$ and the lowest was recorded in December $\left(17.90 \mu \mathrm{g} \mathrm{g}^{-1}\right)$.

Lead - In the North area, the highest value of lead was in July $\left(11.70 \mu \mathrm{g} \mathrm{g}^{-1}\right)$, followed by May $\left(10.99 \mu \mathrm{g} \mathrm{g}^{-1}\right)$, and the lowest was in September under the limit detection $\left(1.62 \mu \mathrm{g} \mathrm{g}^{-1}\right)$. From December 2000 to April 2001, there were small variations in the lead concentrations oscillating between $2.50 \mu \mathrm{g} \mathrm{g}^{-1}$ and 3.00 $\mu \mathrm{g} . \mathrm{g}^{-1}$. In the South area, the highest value was in August $\left(14.00 \mu \mathrm{g} \mathrm{g}^{-1}\right)$, and the lowest was under the limit of detection $\left(1.62 \mu \mathrm{g} \mathrm{g}^{-1}\right)$ in December.

\subsection{Heavy metals in Hypnea musciformis (Fig. 2)}

Iron - The highest content in the North area was in February $\left(1,163 \mu \mathrm{g} \mathrm{g}^{-1}\right)$, followed by October $\left(1,112 \mu \mathrm{g} \mathrm{g}^{-1}\right)$, and the lowest value was in December (279 $\left.\mu \mathrm{g} \mathrm{g}^{-1}\right)$. The highest content to the South occurred in March $\left(1,576 \mu \mathrm{g} \mathrm{g}^{-1}\right)$, followed by September $\left(1,290 \mu \mathrm{g} \mathrm{g}^{-1}\right)$ and July $\left(1,234 \mu \mathrm{g} \mathrm{g}^{-1}\right)$, while the lowest was observed in June $\left(374 \mu \mathrm{g} \mathrm{g}^{-1}\right)$. Likewise the North area, the seasonal variation was very irregular. In general, for both studied areas the iron values showed a very irregular distribution pattern. 

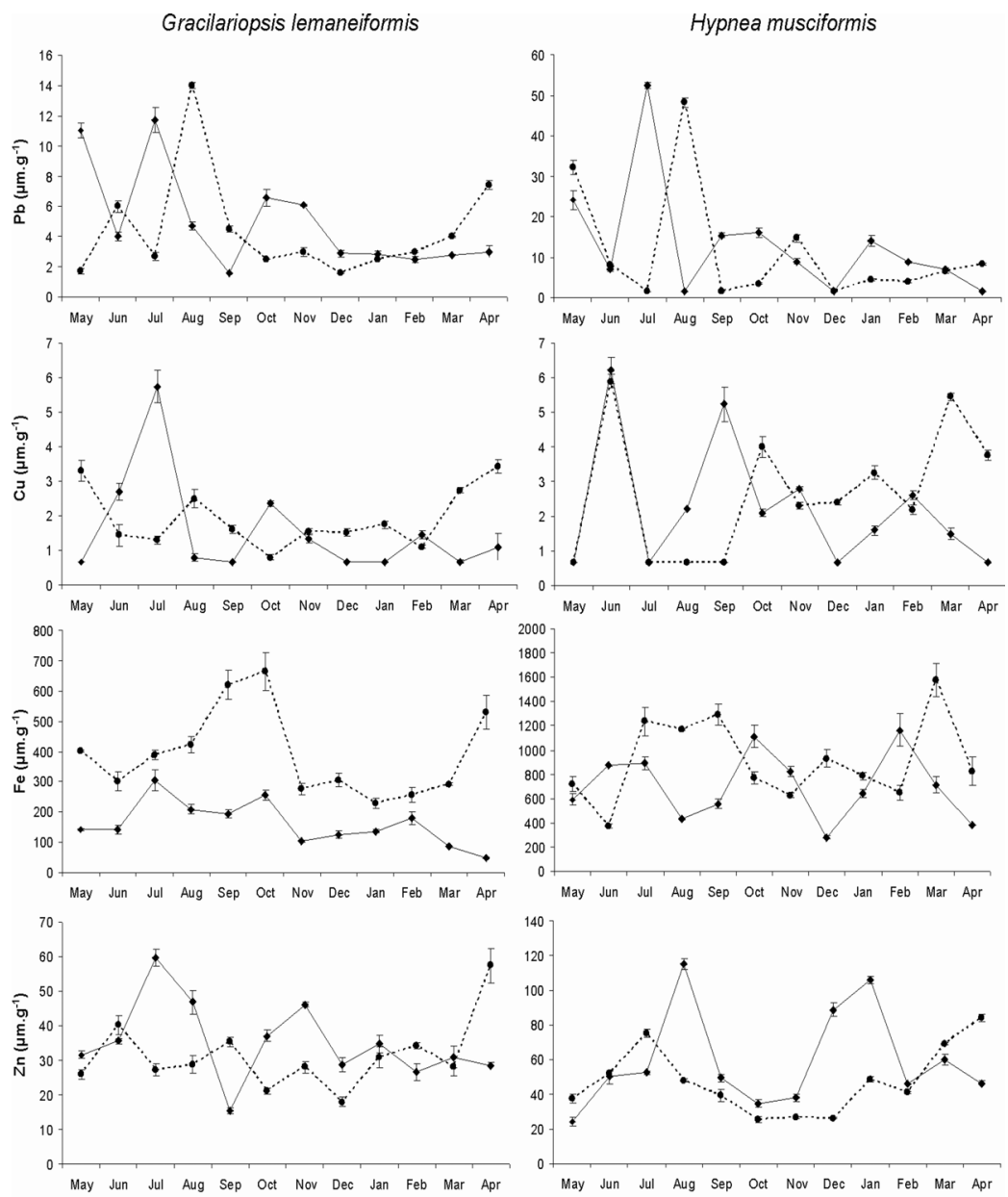

\section{North $^{\prime}$ South}

Figure 2: $\quad$ Metal concentrations in macroalgae from May 2000 to April 2001 in the Pernambuco coastal area, tropical Brazil.

Copper - In the North area, the highest values of copper occurred in June (6.20 $\left.\mu \mathrm{g} \mathrm{g}^{-1}\right)$, followed by September $\left(5.23 \mu \mathrm{g} \mathrm{g}^{-1}\right)$, while the lowest values were under the limit of detection $\left(0.674 \mu \mathrm{g} \mathrm{g}^{-1}\right)$ occurring in May, June, December and April. In the South area, the highest value was registered in June $\left(5.89 \mu \mathrm{g} \mathrm{g}^{-1}\right)$, followed by March $\left(5.44 \mu \mathrm{g} \mathrm{g}^{-1}\right)$, while the lowest value was under the limit of detection $\left(0.674 \mu \mathrm{g} \mathrm{g}^{-1}\right)$ in May, June, August and September. No regular pattern was registered to both studied areas. 
Zinc - The highest amount of zinc in the North area was in January (196.03 $\mu \mathrm{g} \mathrm{g}^{-}$ $\left.{ }^{1}\right)$, followed by August $\left(114.98 \mu \mathrm{g} \mathrm{g}^{-1}\right)$. The lowest value was $24.17 \mu \mathrm{g} \mathrm{g}^{-1}$ in May. In the South area, the highest content of this metal occurred in April (84.14 $\left.\mu \mathrm{g} \mathrm{g}^{-1}\right)$, while the lowest was in October $\left(25.53 \mu \mathrm{g} \mathrm{g}^{-1}\right)$. No regular pattern was registered to both studied areas.

Lead - In the North area, the highest value was in July $\left(52.47 \mu \mathrm{g} \mathrm{g}^{-1}\right)$, and the lowest was under the limit of detection $\left(1.62 \mu \mathrm{g} \mathrm{g}^{-1}\right)$ in August, December and April. In the South area, the highest content was in August (48.19 $\left.\mu \mathrm{g} \mathrm{g}^{-1}\right)$, and under the limit of detection (1.62 $\mu \mathrm{g} g-1)$ occurring in July, September and December.

\subsection{Principal components analysis}

The first and second factors explained $50.45 \%$ of the total data variance. The bidimensional projection (Fig. 3) shows on the right side the rainfall fundamental role, influencing a greater absorption of metals by the macroalgae. Iron and lead were important to both Gracilariopsis carolinensis and Hypnea musciformis and copper and zinc to $G$. carolinensis. On the left side of the projection, it can be observed that the copper content in $H$. musciformis was influenced by the temperature, salinity and dissolved oxygen. In our study the nutrient salts were not relevant in the absorption of metals by the studied macroalgae species.

\section{Discussion}

The macroalgae most extensively used for monitoring heavy metal contamination of water belong to the genera Fucus, Enteromorpha, Laminaria and Ulva [14]. In the present research with Gracilariopsis and Hypnea we found higher iron, copper and zinc values than in the studies carried out with macroalgae in the Brazilian Arquipélago de Abrolhos (65 km from the coast) and Viçosa Reefs (10 km from the coast), both belonging to Bahia State (Brazil) by Amado Filho et al. [15].

In Baía de Sepetiba, Rio de Janeiro (Brazil), zinc contents were evaluated in Padina gymnospora and the results compared with other species (Ulva lactuca, Sargassum filipendula and Hypnea musciformis), being concluded that $P$. gymnospora accumulates zinc directly proportional to its concentration in the water, due the cell wall deposition mechanism [16]. In the species studied in the areas of Itamaracá and Piedade, the median contents of zinc were lower than those found by the above mentioned authors, except for the values recorded for Gracilariopsis lemaneiformis in the North area.

Studies on the seasonal accumulation of metals by Gracilaria verrucosa algae, in the Gulf of Thermaikos, Greece, showed that the seasonal variation in the algae concentrations was significant for cadmium and iron [17]. Copper and iron increased from winter to summer, while cadmium was the opposite. The zinc concentrations were minimal and those of lead were maximal during the spring [17]. In the present studied area, lead and copper had higher values in the 


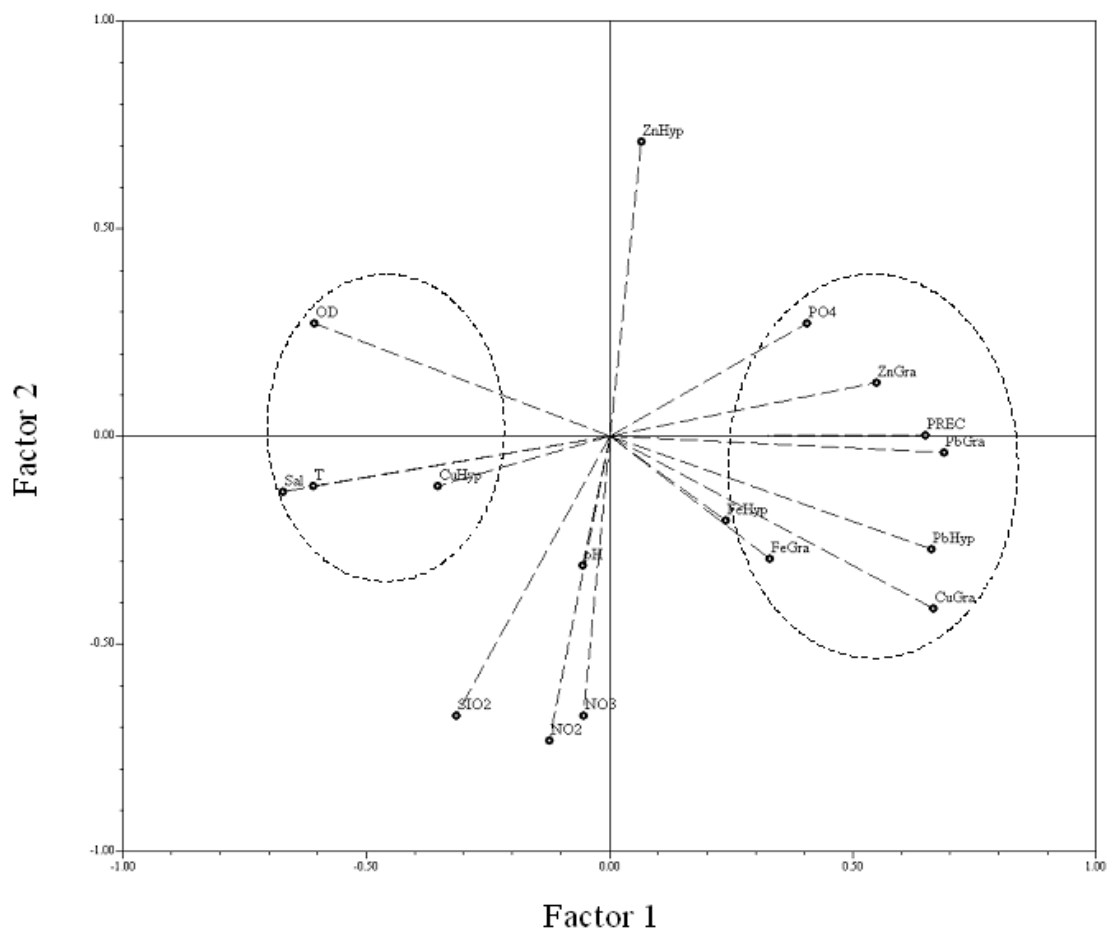

Figure 3: Principal components analysis of heavy metal concentration in red macroalgae from the Pernambuco coastal area, Brazil. PREC=rainfall, $\quad \mathrm{T}=$ temperature,$\quad$ Sal $=$ salinity,$\quad \mathrm{OD}=$ dissolved oxygen, $\quad \mathrm{NO} 2=$ nitrite, $\quad \mathrm{NO} 3=$ nitrate, $\quad \mathrm{PO} 4=$ phosphate, $\mathrm{SIO} 2=$ silicate, Gra $=$ Gracilariopsis carolinensis, Hyp=Hypnea musciformis $\mathrm{Fe}=$ iron, $\mathrm{Zn}=\mathrm{zinc}, \mathrm{Cu}=$ copper, $\mathrm{Pb}=$ lead.

winter (rainy season), while the iron concentrations were higher in the summer (dry season) in the North area for G. lemaneiformis and in the winter (rainy season) in the South area for $H$. musciformis. The zinc concentrations were higher in the winter (rainy season) for both algae studied.

The results obtained in our study with the red algae Gracilariopsis carolinensis and Hypnea musciformis showed that the contents of copper, lead, zinc and iron were in most cases lower than those reported for areas regarded as polluted.

Results of studies carried out in other tropical coastal area [18] showed that all macroalgae species are equally capable to accumulate heavy metals. Concentrations of heavy metals in macroalgae showed that the most uptake of $\mathrm{Zn}$ was in Hypnea sp. (45.2 ppm) and the lowest was in Gracilaria arcuata (12.1 $\mathrm{ppm})$. The most uptake of $\mathrm{Cu}$ was in Codium sp. (23.3 ppm) and the lowest was in Gracilaria corticata (7.8 ppm). The most uptake of $\mathrm{Pb}$ was in Dictyosphaeria covernosa (60 ppm) and the lowest was in Acanthophora musoides (65 ppm). 
Copper, iron, lead, manganese, and zinc contents were determined in various phyla of macroalgae typical of the rocky mesolittoral zone of Cuba and widely distributed in the Caribbean Region [19] a very similar region like in our study. It is interesting to note that the samples were collected in different zones along the shores of Havana City which are more or less influenced by anthropogenic activities. Differences in metal contents were observed due to seasonal variations and differences between sampling sites. However, of the analyzed species, only one brown alga, Padina vickersiae was considered as a suitable candidate for the monitoring of metal contamination [19].

Studies carried out in the Black Sea ecosystems [20] showed that the red algae species (Rhodophyta) accumulate more heavy metals than the other phyla (except for Fe whose values were higher in green algae). The data confirmed that algae are valuable indicators of the environmental contamination. The observed elevated levels were mainly due to the rivers Danube, Dnieper and Dnester inputs in the NW corner of the Black Sea. These results are similar to our study and show the important role of red macroalgae as bioindicator of heavy metals.

Comparing the studied areas in Pernambuco State, it was observed that the zinc, lead and iron concentrations in the North area were higher than those of the South area, and the copper concentration being higher in the South area. In general, Hypnea musciformis in both areas accumulated higher metals concentration, suggesting that this macroalgae can be used as a heavy metal monitor to Pernambuco coastal area (Brazil). However, we suggest that more studies in this field should be done with other macroalgae species and also the effect of these contaminated macroalgae to herbivorous.

The rainfall was the parameter that presented greater influence on the metals accumulation, while salinity was the most relevant factor in the environment, preventing absorption of metals in the algae. A high degree of seasonal variation was observed between the two areas; however no pattern could be established to the metals concentration of the two macroalgae species.

It our study it was possible to establish a reference value to Hypnea musciformis and to Gracilariopsis lemaneiformis, and to validate a methodology for the Northeastern Brazil.

\section{References}

[1] Volesky, B. (1990). Biosorption of heavy metals, Ed. CRC Press; Florida.

[2] Phillips, D. (1977). The use of biological indicator organisms to monitor trace metal pollution in marine and estuarine environments - a review. Environ. Pollut. 13: 281-317.

[3] Levine, H. (1984). The use of seaweeds for monitoring coastal waters. In: Schubert L (ed) Algae as ecological indicators. Academic Press, N.Y., pp. 189-210.

[4] Garnham, G.; Codd, G. \& Cadd, G. (1992). Kinetics of uptake and intracellular location of cobalt, manganese and zinc in the estuaries green alga Chlorella saline. Appl. Microbiol. Biotechnol. 37: 270-276 
[5] Barreiro, R.; Real, C. \& Carballeira, A. (1993). Heavy metal accumulation by Fucus ceramoides in a small estuary in north-west Spain. Mar. Environ. Res. 36: 39-61.

[6] Martoja, M.S. \& Martoja, R. (1984). La Bioacumulation de metaux mrocess physiologique normal et consequence de la pollution. Le Courrier do CNRS 54: 32-37.

[7] Villares, R.; Puente, X. \& Carballeira, A. (2002). Seasonal variation and background levels of heavy metals in two green seaweeds. Environ. Pollut. 119: 79-90.

[8] Oliveira Filho, E.C. (1981). A exploração de algas marinhas no Brasil. In: Accleto, C. et al. (ed). Phycologia Latino Americana. Germany, v.1, p. 518.

[9] Oliveira Filho, E.C. (1998). The seaweeds resources of Brazil. In: Critcheley, A.T. \& Ohno, M. (ed.). Seaweeds resources of the world. 8. Japan International Cooperation Agency. Yokosuka, p.366-371.

[10] Braile, P.M. \& Cavalcanti, J.E.W.A. (1979). Manual de Tratamento de Águas Residuárias Industriais. São Paulo, CETESB, 764p.

[11] Macedo, S.J.; Silva, H.K.P.; Brayner, F.M.M.; Duarte, M.M.M.B. \& Barbosa, A.M.F. (2007). Heavy metal concentrations in sediments of the Capibaribe River estuary in the metropolitan region of Recife, Pernambuco, Brazil. Proc. of the $3^{\text {rd }}$ Int. Conf. on Sustainable Development and Planning, eds. A. Kungolos, C.A. Brebbia \& E. Beriatos, WIT Press: Southampton, vol. 1, pp.357-376.

[12] Aragão, J. O. R. (2004). A influência dos oceanos Pacífico e Atlântico na dinâmica do tempo e do clima do Nordeste do Brasil. In: Eskinazi-Leça, E.; Neumann-Leitão, S. \& Costa, M. F. (eds.) Oceanografia - Um cenário tropical. Recife, pp. 287-317.

[13] Kane, J.S. (1992). Reference samples for use in analytical geochemistry: their availability, preparation and appropriate use. J. Geochem. Explot. 44:.37-63.

[14] Fytianos K.; Evgenidou, E. \& Zachariadis, G. (1999). Use of macroalgae as biological indicators of heavy metal pollution in Thermaikos Gulf, Greece. Bull. Environ. Contamin. Toxicol. 62(5): 630-637.

[15] Amado Filho, G.M.; Andrade, L.R.; Reis, R.P.; Bastos, W. \& Pfeiffer, W.C. (1995). Heavy metal concentrations in seaweed species from the Abrolhos reef region, Brazil. Proc $8^{\text {th }}$ Int Coral Reef Sym, Rio de Janeiro, v. 2, p. $1843-1846$.

[16] Amado Filho, G.M.; Karez, C.S.; Pfeiffer W.C., Yoneshigue-Valentin, Y. \& Farina, M. (1996). Accumulation, effects on growth, and localization of zinc in Padina gymnospora (Dictyotales, Phaeophyceae). Hydrobiologia 326/327:451-456.

[17] Malea, P \& Haritonides, S. (1999). Seasonal accumulation of metals by red alga Gracilaria verrucosa (Huds.) Papens. from Thermaikos Gulf, Greece. J. Appl. Phycol. 11: 503-509.

[18] Shahidi, S.; Nejatkhah Manavi, P. \& Shirvani Mahdavi, E. (2008). Study of heavy metals $(\mathrm{Zn}, \mathrm{Cu}, \mathrm{Pb})$ in water and macroalgae in intertidal zone of 
Bushehr. International Conference on "Monitoring \& modeling of marine pollution" 1-3 December 2008, Kish Island- Islamic Republic of IRAN. http://www.inco.ac.ir/incomp2008/Abstract/PDF/

[19] Ramirez, M.; González, H.; Ablanedo, N. \& Torres, I. (1990). Heavy metals in macroalgae of Havana's Northern littoral, Cuba. Chem. Ecol. 4 (2): $49-55$.

[20] Strezov, A. \& Nonova, T. (2009). Influence of macroalgal diversity on accumulation of radionuclides and heavy metals in Bulgarian Black Sea ecosystems. J. Environ. Radioact. 100(2): 144-150. 